\title{
Raising Perceptions on Corporate Social Responsibility for Achieving Sustainable Development Goals
}

\author{
Subrata Kumer Pal \\ Lecturer, Dept. Of Management, New Government Degree College \\ Rajshahi-6000, Bangladesh \\ Tel: 880-174-573-7684Ｅ-mail: subrata1990.ru@gmail.com
}

Pramath Chandra Sarker

Lecturer, Dept. Of Psychology, Rajshahi College, Rajshahi-6000, Bangladesh

Tel: 880-171-492-5923Ｅ-mail: pramath588@gmail.com

\author{
Shibu Chandra Odhikari \\ Lecturer, Dept. Of History, Chilahati Government College, Nilphamari-5300, Bangladesh \\ Tel: 880-173-717-0868Ｅ-mail: odhikari36@gmail.com
}

Received: November 23, 2021 Accepted: December 19, 2021 Published: January 8, 2022

doi:10.5296/ber.v12i1.19223ＵRL: https://doi.org/10.5296/ber.v12i1.19223

\begin{abstract}
The Sustainable Development Goals (SDGs) 2030 is the United Nations development agenda for developing the economy, society, and environment. Moreover, Corporate Social Responsibility (CSR) is an emerging topic in the business world. The paper aims to pursue business students' knowledge and perception of CSR activities linked to SDGs. The quantitative research design and descriptive research analysis were used. The data were collected from business learning students of three public universities in Bangladesh. CSR's perception-related items positively correlated with Spearman's Rho's formula. The descriptive statistics revealed perceptions of CSR activities among respondents, which are directly and indirectly related to SDGs. In addition, the two-tailed Mann-Whitney $U$ test and Kruskal-Wallis $H$ test showed a variation of perceptions among groups. The findings of this study showed respondents had an acceptable knowledge level on CSR activities. There was a positive perception of respondents on economic and social dimensions of SDGs and mainly
\end{abstract}


included in philanthropic and economic fields of CSR. Besides, their consciousness of the environmental dimension related to ethical and legal activities of CSR concepts was comparatively low. Finally, favourable knowledge and perception of business studying students in CSR activities are imperative for the successful implementation of SDGs.

Keywords: Business, Corporate Social Responsibility, Emerging Economy, Perception, Sustainable Development Goals

\section{Introduction}

At present, CSR is an integral part of business, and it is a driving force of business sustainability, social development, and environmental conservation. CSR activities are also contributing various ways in business institutions. On the other hand, education in business and commercial areas plays vital roles in companies and industries directly and indirectly. Business schools and their higher education contribute various ways to a firm's performance and entrepreneurial success (Hunady et al., 2018). De Burgh and Saha (2014) supported a business education and commerce degree to enhance corporate skills comprising ethical obligation, social equity, and environmental issues. This way, business schools and their students affect SDGs by the road of CSR activities (García-Feijoo et al., 2020). CSR and SDGs are co-related; business schools, educational systems, and graduates directly prosecute CSR, indirectly accelerate SDGs.

The economy of Bangladesh is expanding very swiftly compared to other south Asian countries (Moyeen \& West, 2014). In here, many small and large-scale business organizations are performing their activities successfully. CSR is becoming more urgent in small to large-scale organizations for short-term profitability and long-term sufficiency (Masum et al., 2019). But CSR is being practised in limited areas, such as banking sectors guided by Bangladesh Bank and SMEs working as subcontractors forced by foreign companies. Moreover, most of these companies focus on charitable and philanthropic activities denying environmental and legal issues (Moyeen \& West, 2014). So, the application of CSR policies is not satisfactory in Bangladesh.

The research aims at depicting knowledge and perceptions on corporate social responsibility (CSR) aligning with sustainable development goals (SDGs) of business graduate-level students of the public universities in Bangladesh. The study's specific objectives were to measure the knowledge and the perception of business faculty students of the public universities on CSR and show the link between CSR and SDGs.

\section{Literature Review}

In a general sense, the obligations and responsibilities of business to society are called CSR. It encompasses not only community but also broad areas. CSR discusses broad areas covering the economy, society, and environment (ElAlfy et al., 2020). CSR also focuses on attaining business goals and success, keeping intact ethical values, larger public welfare, and no harm to the environment (Chauhan \& Dawra, 2017). CSR concepts have been practised in various countries in different spheres for a long time. In past, organizations were concerned about law and legal issues. But CSR begins when the law ends. An organization is not socially 
responsible unless it operates social obligations outside the law's requirement (Davis, 1973). CSR is a notion of management in which firms connect society and the environment in their activities and interact with their stakeholders (UNIDO, 2002). Stakeholders include shareholders, customers, suppliers, employees, local neighbourhoods, government, and the various environmental factors, directly and indirectly, related to business.

After all, Carroll's definition has covered significant areas of CSR. He (1991) defined CSR as economic, ethical, legal, and philanthropic responsibilities. Thus, CSR is the obligation and responsibility of corporations related to economic, legal, honest, and charitable aspects that collaborate the profitability of the business, society's welfare, and conservation of the environment.

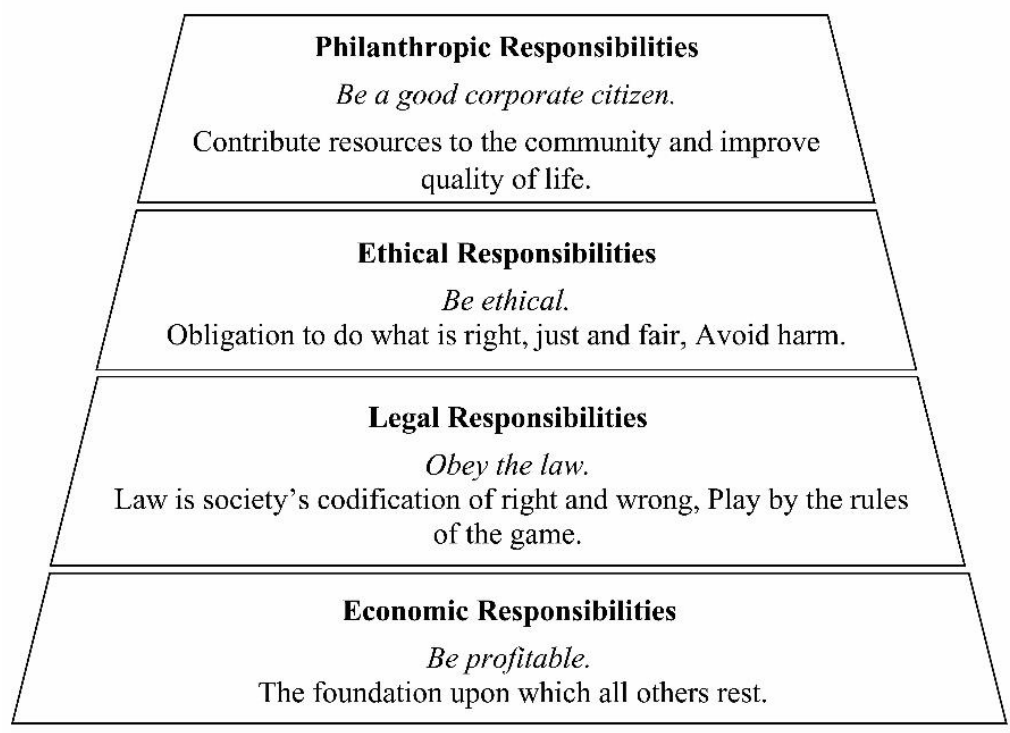

Figure 1. The Pyramid of Corporate Social Responsibility (Carroll, 1991)

CSR is an integral part of business, and it plays an essential role in the industry in various ways. CSR is helpful for the prosperity and success of the company, and it also enhances revenues and reduces different costs (Adda et al., 2016). CSR activities influence reputation, brand, financial capacity, consumer's loyalty and satisfaction, products specialization, market share, the attraction of highly-competent workers, work efficiency and effectiveness, cost minimization, and risk reduction that are crucial to get a competitive advantage for a business (Lu et al., 2020). Thus, CSR activities affect overall organizational performance positively (Nazri et al., 2018). It is a corporate strategy that increases competitive advantage and raises customer satisfaction, goodwill, trust, and loyalty (Islam et al., 2021). Internal CSR practising is helpful to bring job satisfaction among the workforces of an organization (Chan \& Hasan, 2019).

Furthermore, During the COVID-19 pandemic, business organizations assist employees, customers, communities, society, and other vital stakeholders by taking CSR activities (Mahmud et al., 2021). CSR helps to be accountable to society, links business with the 
community, and collaborates between civil society, business, investors, and government based on a win-win policy (Singh \& Misra, 2021). It also impacts the overall business's strategy that contributes to conserving the environment, preventing pollution, reducing waste and recycling, and bringing sustainability to the organization (Boubakary \& Moskolaï, 2016).

The SDGs are a new approach to global governance that is the successor to the Millennium Development Goals (MDGs). Many social and environmental problems have kept human civilization under severe pressures worldwide from the past decades. That lead to a historic universal political understanding in September 2015, when 193 nations signed the reputed SDGs or Global Goals or the United Nations Sustainable Development Goals for 2030 (Pedersen, 2018). It contains 17 Goals, and 169 related targets are interconnected, inseparable and symmetric, including the economic, social, and environmental aspects. SDGs are anticipated to greet better sustainability disclosure (ElAlfy et al., 2020). SDGs are known as the inclusive Goals for making possible all steps to eradicate poverty, preserve the planet, and confirm peace and prosperity of all people by 2030. SDGs are also deliberated as tools and techniques for developing, empowering, and reforming the economy, bringing positive social and political transformation (Rendtorff, 2019). The United Nations (UN) introduced SDGs for alleviating poverty, ensuring a safe planet, peace, and prosperity for present and future generations.

Table 1. The dimensions of sustainability and the Sustainable Development Goals (SDGs) (García-González et al., 2020; Albareda-Tiana et al., 2018)

\begin{tabular}{|l|l|l|}
\hline Economic Dimension & Social Dimension & Environmental Dimension \\
\hline SDG 1- No Poverty & SDG 2- Zero Hunger & SDG 6- Clean Water and \\
SDG 8- Decent Work and & SDG 3- Good Health and Well-Being & Sanitation \\
Economic Growth & SDG 4- Quality Education & SDG 7- Affordable and Clean \\
SDG 9- Industry, Innovation and & SDG 5- Gender Equality & Energy \\
Infrastructure & SDG 11- Sustainability Cities and & SDG 13- Climate Action \\
SDG 10- Reduced Inequalities & Communities & SDG 14- Life Below Water \\
SDG 12- Responsible & SDG 16- Peace, Justice and Strong & SDG 15- Life on Land \\
Consumption and Production & Institutions & \\
& SDG 17- Partnerships for the Goals & \\
\hline
\end{tabular}

Three dimensions of SDGs involve various parts of economic, social and environmental spheres (García-González et al., 2020; Albareda-Tiana et al., 2018). SDGs involve the economic sphere that mainly depicts business activities. On the other hand, the business organization contributes to society and environmental preservation through CSR activities. The goals, the specific targets, and the thousands of indicators describe business organizations' guidelines to work for sustainable development (Pedersen, 2018). Multinational enterprises (MNEs) play vital roles in SDGs relevant innovation, but SDGs have trade-offs among SDGs (Van der Waal et al., 2021). Business stimulates the SDGs agenda positively through a business-oriented approach (Jimenez et al., 2021). SDGs and corporate sustainability work as a global business opportunity and prosperity model equally applicable to different economic and social realities (Pattanaro \& Donato, 2018). 


\subsection{CSR Knowledge}

Education is a vital issue for enhancing CSR knowledge in the academic sector. It is a subject of business institutions, and for all, educational organizations should incorporate CSR into their syllabus (Adámek, 2013). The administrative body or superior authority of institutions with CSR knowledge can quickly establish good governance, bring the best performance, favourable financial returns, and flourish firm responsibilities (Nguyen and Huang, 2020). There is a high requirement of CSR topics in educational organizations for the advantages of internal and external stakeholders of the institutions (Vázquez et al., 2013). The community's favourable knowledge and awareness of CSR motivate organizations to operate and behave ethically and responsibly (Hieu, 2011). In this way, education improves CSR's knowledge and understanding among people and supports CSR's program executions (Karabasevic et al., 2016). Over the past few years, the awareness level of CSR has been increasing day by day in Bangladesh (Ismail, 2011). Business and commerce based academic institutions or divisions are playing vital roles to enhance CSR's awareness among its students in Bangladesh through various programs.

Hypothesis 1: The CSR knowledge among respondents is favourable.

\subsection{CSR Perceptions}

With the economic development in Bangladesh, CSR is getting talkative and emerging issues. CSR has been considered a central issue among business people, academia, and civil society (Belal \& Roberts, 2010). There is no specific law of CSR. The Companies Act 1994 and The Bangladesh Labor Law 2006 guides organizations in limited areas of CSR (Khatun, 2014). On the other hand, the central bank of Bangladesh (Bangladesh Bank) developed CSR guidelines for the first time in 2008. Bangladesh Bank has been publishing CSR reports of financial and non-financial organizations bi-yearly from that time. Besides, there are seven broad categories of CSR programs: reliefs for humanity and disaster, health care, educational help, cultural development, environment conservation, infrastructural advancement, and creating earning facilities (Mahmud et al., 2020). Regrettably, CSR is practised chiefly in limited aspects, like philanthropy, law, ethics, and economy. Bangladeshi companies are usually concerned about employee-related CSR activities but pay less attention to environmental elements (Masum et al., 2019).

On the other hand, CSR activities don't cover all areas as the global perspectives. A recent study on CSR of the banking sector showed that societal needs are more critical than GRI guidelines as well as CSR practices are culturally dependent, not globally accepted (Ndiweni et al., 2018). Besides, SMEs working directly or indirectly as subcontractors of the large-suppliers face problems in accessing global markets due to their inability to maintain the globalized CSR guidelines intended by large international buyers (Rahim \& Wisuttisak, 2013). CSR plays a crucial role in economic progress, sustainable development, and social welfare. It has become an attentive matter among the research community and government, lawmakers, politicians, business people, civil society, social workers, and NGOs (Khatun, 2014). Corporate stakeholders as employees, owners, managers, government, society, suppliers, customers, and others are direct or indirect beneficiaries of CSR in various ways. 
However, a positive perception of CSR uniformly among the business community is significant for attaining SDGs (Moyeen \& West, 2014). People's positive feeling and consciousness on CSR is crucial for the practical application of CSR's concept. But there is a lack of positive public perception and participation in CSR in Bangladesh (Rana, 2015).

Hypothesis 2: There is a lack of favourable perception of CSR among respondents.

\subsection{CSR and SDGs}

CSR and SDGs are two essential topics interrelated to each other. SDGs are a cogent model for businesses organizations to work on CSR. Inter-relating factors, such as industry, water, education, and gender, link SDGs with CSR (Chauhan \& Dawra, 2017). The Earth Summit by the United Nations Conference on Environment and Development (UNCED) presented CSR as the sustainability documents in 1992 at Rio de Janeiro. Similarly, in 2002 the Johannesburg Summit by World Summit on Sustainable Development (WSSD) focused on CSR and accountability of large and small businesses contributing to sustainable development (Behringer \& Szegedi, 2016). CSR and SDGs are necessary applied and promoted notions by companies globally (Mai, 2013). CSR is a model that flourishes a business to contribute to SDGs. It brings the spirit of SDGs into the business strategy for economic benefits, environmental preservation, and social development (Behringer \& Szegedi, 2016). CSR is the idea of sustainable development at a corporate level that plays a critical role in any enterprise and tries to achieve its long-term goals (Nguyen et al., 2020). CSR supports SDGs clearly and helps companies, managers, employees, shareholders, and stakeholders to know the society (Juneja, 2014). CSR activities are first related to economic and social and environmental areas. Thus, various areas of SDGs can be achieved through the CSR activities of the business organizations.

Hypothesis 3: There is a relationship between CSR and SDGs.

\section{Methodology}

Quantitative research was considered applicable in this study and anticipated for measuring knowledge and perception of CSR by business studies students. In this study, the population consisted of various aged students under several subjects of business studies from three public universities in Bangladesh. The convenience sampling method under a non-probability sample design was appropriate for this research. In this paper, 100 respondents were selected as per the agreement of most statisticians (Tool4dev, 2021). Besides, Kish (1965) stated minimum sample size in social science research should be 30-200.

In the research, the online survey was directed by a fully structured questionnaire consisting of closed-ended questions with several options for respondents to choose from. In the online survey, the survey link of google Forms was circulated in email, text message, Facebook page, Facebook groups, and messenger groups. Beyond those, respondents were requested to refer to others like snowball sampling. Because of the non-speaking citizens in Bangladesh, the questionnaire was translated by an interpreter from English to Bengali and sent to two experts in business areas. This questionnaire incorporated their recommendations. Ethical considerable issues such as respondent's confidentiality and anonymity, data privacy, and 
compliance were maintained carefully.

The questionnaire of this research consisted of three parts. Part A narrated socio-demographic data, including age, gender, education levels, subjects, career choice, and university of respondents. Part B represented CSR education knowledge, followed by Kot (2014). Part C was designed to determine students' perceptions of CSR related to SDGs and obtained from the CSR's pathways of Gupta (2019) and CSRPs activities narrated by Mahmud et al. (2020). A five-point Likert scale from $1=$ strongly disagree $(\mathrm{SD})$ to $5=$ strongly agree $(\mathrm{SA})$ was used to measure perceptions.

\section{Results and Discussion}

The majority of the respondents were male, $75 \%$ and the remaining $25 \%$ were female respondents presented in Table 2. About the fourth-fifths of the respondents were aged between 16-22 years, and the rest were aged from 23 to 30 years. The majority of the respondents studied at the undergraduate level, and only $18 \%$ were at the graduate level. All of the respondents were from ten subject areas from the business faculty. More than half preferred government service for future careers, and the rest chose private sectors and entrepreneurship. Most of them were from the University of Rajshahi.

Table 2. Socio-demographic Characteristics of Respondents

\begin{tabular}{|c|c|c|c|}
\hline Variables & Sub-Variables & Frequency $n=100$ & Percentage $(\%)$ \\
\hline \multirow[t]{2}{*}{ Age } & 16-22 years & 82 & 82.0 \\
\hline & 23-30 years & 18 & 18.0 \\
\hline \multirow[t]{2}{*}{ Gender } & Male & 75 & 75.0 \\
\hline & Female & 25 & 25.0 \\
\hline \multirow{2}{*}{$\begin{array}{l}\text { Education } \\
\text { Level }\end{array}$} & Honours (Undergraduate) & 82 & 82.0 \\
\hline & Masters (Graduate) & 18 & 18.0 \\
\hline \multirow[t]{5}{*}{$\begin{array}{l}\text { Subjects of } \\
\text { Respondents }\end{array}$} & $\begin{array}{l}\text { Management / Human Resource } \\
\text { Management / Management Information System }\end{array}$ & 63 & 63.0 \\
\hline & Accounting / Accounting Information System & 15 & 15.0 \\
\hline & $\begin{array}{l}\text { Finance / Finance and Banking / } \\
\text { Insurance and Banking }\end{array}$ & 10 & 10.0 \\
\hline & Marketing & 8 & 8.0 \\
\hline & Institute of Business Administration & 4 & 4.0 \\
\hline \multirow[t]{3}{*}{ Career Choice } & Government service & 52 & 52.0 \\
\hline & Private service / non-government organization & 21 & 21.0 \\
\hline & Entrepreneur & 27 & 27.0 \\
\hline \multirow[t]{3}{*}{ University Name } & University of Rajshahi & 67 & 67.0 \\
\hline & University of Dhaka & 14 & 14.0 \\
\hline & Begum Rokeya University, Rangpur & 19 & 19.0 \\
\hline
\end{tabular}

All of the respondents knew about CSR in Table 3. Around half of them learned about CSR at their secondary level, while half in higher secondary and undergraduate levels. About $55 \%$ of respondents studied CSR as a chapter, 30\% read it as a chapter topic, and 15\% learned it as a course. Overall, respondents had studied CSR in different portions. Based on their CSR's education, the awareness level of CSR was favourable. 
Table 3. Knowledge of CSR

\begin{tabular}{|l|l|l|l|}
\hline Variables & Sub-variables & Frequency (n=100) & Percentage (\%) \\
\hline Known about the term CSR & Yes & 100 & 100.0 \\
\hline \multirow{2}{*}{$\begin{array}{l}\text { Known about CSR at } \\
\text { the education level. }\end{array}$} & $\begin{array}{l}\text { Secondary School Certificate (SSC) or } \\
10^{\text {th }} \text { Class or O level }\end{array}$ & 28 & 28.0 \\
\cline { 2 - 4 } & $\begin{array}{l}\text { Higher Secondary Certificate (HSC) } \\
\text { or 12 }\end{array}$ & 51 & 51.0 \\
\cline { 2 - 4 } & Honours (Undergraduate) & 21 & 21.0 \\
\hline Quantity of Study on CSR & A chapter & 55 & 55.0 \\
\cline { 2 - 4 } & A topic of chapter & 30 & 30.0 \\
\cline { 2 - 4 } & A subject/course & 15 & 15.0 \\
\hline
\end{tabular}

The expected average inter-item correlation range for broad higher-order construct to be 0.15 to 0.20 and 0.40 to 0.50 for narrow-order (Clark \& Watson, 1995). Likewise, almost all psychometricians consented that Cronbach's alpha value of 0.70 was allowable. Therefore, Table 4 shows the internal consistency reliability of the following items was acceptable.

Table 4. Internal Consistency Reliability

\begin{tabular}{|l|l|l|l|}
\hline Dimensions & Number of variables & Cronbach's alpha & Average inter-item correlation (AIC) \\
\hline Perception of CSR & 21 & 0.888 & 0.277 \\
\hline Economic & 6 & 0.792 & 0.396 \\
\hline Social & 9 & 0.832 & 0.354 \\
\hline Environmental & 6 & 0.845 & 0.477 \\
\hline
\end{tabular}

Table 5 represents descriptive statistics of the perception of students on CSR through three dimensions of SDGs. In the economic dimension, the business organization's six CSR activities exposed positive feelings on these items. About $99 \%$ of the students agreed to removing poverty and generating job facilities. All of them acceded to infrastructure development and abating inequality among various people. Thus, around $98 \%$ of the respondents had favourable perception about fair payment to the organization's workforces and proper management of rubbish spawned by internal operations of the business.

In the second dimension of this table, all students supported donating medical facilities, monetary aid in education, and gender equality in the workplace. Except all, only a single respondent was neutral in the case of food security, community advancement, and growing road safety. In these ways, about $98 \%$ to $96 \%$ of students favoured strengthening the organization, establishing peace and justice in the community, and partnership with interest groups and government.

A differential scenario was observed in the last environmental areas where more than $20 \%$ of respondents answered "Neutral." Fourth-fifths of them perceived positively in pure water, affordable clean energy, controlling greenhouse effect and forestation projects. On the other hand, about $75 \%$ of students clearly understood sea life's protraction and land conservation. 
Table 5. Descriptive Statistics on the Perception of CSR

\begin{tabular}{|c|c|c|c|c|c|c|}
\hline & Items & Mean & Median & Standard Deviation & Min & Max \\
\hline & Economic dimension (ECO) & & & & & \\
\hline$E C O 1$ & $\begin{array}{l}\text { Financial support to the poor and help to } \\
\text { eliminate poverty. }\end{array}$ & 4.49 & 4.50 & .522 & 3 & 5 \\
\hline$E C O 2$ & $\begin{array}{l}\text { Minimum wages and other facilities to } \\
\text { employees. }\end{array}$ & 4.38 & 4 & .528 & 3 & 5 \\
\hline$E C O 3$ & $\begin{array}{l}\text { Employment creation and arrange } \\
\text { training programs for people. }\end{array}$ & 4.31 & 4 & .486 & 3 & 5 \\
\hline$E C O 4$ & $\begin{array}{l}\text { Constructing roads, bridges, culverts, } \\
\text { ports, and smart factories. }\end{array}$ & 4.31 & 4 & .465 & 4 & 5 \\
\hline ECO 5 & $\begin{array}{l}\text { Support and inclusion of minorities, } \\
\text { women, widows, and disabled people. }\end{array}$ & 4.32 & 4 & .469 & 4 & 5 \\
\hline ECO 6 & $\begin{array}{l}\text { Reduction of plastic and polyethene use } \\
\text { and recycling factories wastages. }\end{array}$ & 4.37 & 4 & .525 & 3 & 5 \\
\hline & Social dimension ( $\mathrm{SCO}$ ) & & & & & \\
\hline $\mathrm{SCO} 1$ & Ensuring food safety and product purity. & 4.36 & 4 & .503 & 3 & 5 \\
\hline $\mathrm{SCO} 2$ & $\begin{array}{l}\text { Donation to hospitals and provide free } \\
\text { medical treatment. }\end{array}$ & 4.38 & 4 & .488 & 4 & 5 \\
\hline $\mathrm{SCO} 3$ & $\begin{array}{l}\text { Assisting poor students and providing } \\
\text { scholarships. }\end{array}$ & 4.49 & 4 & .502 & 4 & 5 \\
\hline $\mathrm{SCO} 4$ & $\begin{array}{l}\text { Funding for playgrounds, transportation, } \\
\text { playing instruments, and medical } \\
\text { equipment. }\end{array}$ & 4.25 & 4 & .458 & 3 & 5 \\
\hline SCO 5 & Raising awareness of road accidents. & 4.26 & 4 & .463 & 3 & 5 \\
\hline SCO 6 & $\begin{array}{l}\text { Preserving employee rights, internal } \\
\text { transparency, and accountability of the } \\
\text { organization. }\end{array}$ & 4.35 & 4 & .539 & 3 & 5 \\
\hline SCO 7 & $\begin{array}{l}\text { It builds public awareness of women's } \\
\text { oppression, rape, child marriage, } \\
\text { trafficking, child labour, and other social } \\
\text { problems. }\end{array}$ & 4.25 & 4 & .520 & 3 & 5 \\
\hline$S C O 8$ & $\begin{array}{l}\text { Keeping relationships with stakeholders } \\
\text { of the organization. }\end{array}$ & 4.27 & 4 & .529 & 3 & 5 \\
\hline \multirow[t]{2}{*}{$S C O 9$} & $\begin{array}{l}\text { Taking part in development activities } \\
\text { with the government. }\end{array}$ & 4.43 & 4 & .537 & 3 & 5 \\
\hline & Environmental dimension (ENV) & & & & & \\
\hline$E N V 1$ & $\begin{array}{l}\text { Waning water pollution by following } \\
\text { environmental laws. }\end{array}$ & 3.85 & 4 & .479 & 3 & 5 \\
\hline$E N V 2$ & $\begin{array}{l}\text { Saving the environment by using green } \\
\text { and renewable energy. }\end{array}$ & 3.86 & 4 & .513 & 3 & 5 \\
\hline$E N V 3$ & Minimizing greenhouse gas emissions. & 3.86 & 4 & .493 & 3 & 5 \\
\hline$E N V 4$ & $\begin{array}{l}\text { Preventing sea pollution and conserving } \\
\text { sea assets. }\end{array}$ & 3.81 & 4 & .526 & 3 & 5 \\
\hline$E N V 5$ & $\begin{array}{l}\text { Defending deforestation and diminishing } \\
\text { soil pollution }\end{array}$ & 3.81 & 4 & .545 & 3 & 5 \\
\hline ENV 6 & Arranging tree plantation programs & 3.84 & 4 & .487 & 3 & 5 \\
\hline
\end{tabular}

In Table 6, Spearman's Rho Correlations among economic variables were positive and significant. Therefore, the positive correlation indicated the validity of variables (Karras, 1997). The highest correlation coefficient was between ECO 3 and ECO 5, 0.629 ( $\mathrm{p}<0.01$ ). Most of the values were positively correlated in moderated and good levels (Akoglu, 2018). 
Similarly, Table 7 and 8 represented a positive association among social and environmental variables.

Table 6. Spearman's Rho Correlations of Economic Variables

\begin{tabular}{|l|l|l|l|l|l|l|}
\hline & ECO 1 & ECO 2 & ECO 3 & ECO 4 & ECO 5 & ECO 6 \\
\hline ECO 1 & 1 & & & & & \\
\hline ECO 2 & .187 & 1 & & & & \\
\hline ECO 3 & $.303^{* *}$ & $.421^{* *}$ & 1 & & & \\
\hline ECO 4 & $.411^{* *}$ & $.340^{* *}$ & $.558^{* *}$ & 1 & & \\
\hline ECO 5 & $.387^{* *}$ & $.279^{* *}$ & $.629^{* *}$ & $.560^{* *}$ & 1 & \\
\hline ECO 6 & $.324 * *$ & $.302^{* *}$ & $.506^{* *}$ & $.414^{* *}$ & $.437^{* *}$ & 1 \\
\hline
\end{tabular}

**. Correlations is significant at the 0.01 level (2-tailed)

Table 7. Spearman's Rho Correlations of Social Variables

\begin{tabular}{|l|l|l|l|l|l|l|l|l|l|}
\hline & SCO 1 & SCO 2 & SCO 3 & SCO 4 & SCO 5 & SCO 6 & SCO 7 & SCO 8 & SCO 9 \\
\hline SCO 1 & 1 & & & & & & & & \\
\hline SCO 2 & .175 & 1 & & & & & & & \\
\hline SCO 3 & $.211^{*}$ & $.510^{* *}$ & 1 & & & & & & \\
\hline SCO 4 & $.229^{*}$ & $.385^{* *}$ & .161 & 1 & & & & & \\
\hline SCO 5 & .166 & $.421^{* *}$ & $.281^{* *}$ & $.410^{* *}$ & 1 & & & & \\
\hline SCO 6 & $.446^{* *}$ & $.293^{* *}$ & $.222^{*}$ & $.386^{* *}$ & $.378^{* *}$ & 1 & & & \\
\hline SCO 7 & $.280^{* *}$ & $.318^{* *}$ & $.385^{* *}$ & $.380^{* *}$ & $.477^{* *}$ & $.448^{* *}$ & 1 & & \\
\hline SCO 8 & $.216^{*}$ & $.394^{* *}$ & $.231^{*}$ & $.484^{* *}$ & $.510^{* *}$ & $.456^{* *}$ & $.523^{* *}$ & 1 & \\
\hline SCO 9 & $.437^{* *}$ & $.374^{* *}$ & $.292^{* *}$ & $.354^{* *}$ & $.374^{* *}$ & $.504^{* *}$ & $.365^{* *}$ & $.596^{* *}$ & 1 \\
\hline
\end{tabular}

Table 8. Spearman's Rho Correlations of Environmental Variables

\begin{tabular}{|l|l|l|l|l|l|l|}
\hline & ENV 1 & ENV 2 & ENV 3 & ENV 4 & ENV 5 & ENV 6 \\
\hline ENV 1 & 1 & & & & & \\
\hline ENV 2 & $.437^{* *}$ & 1 & & & & \\
\hline ENV 3 & $.513^{* *}$ & $.607 * *$ & 1 & & & \\
\hline ENV 4 & $.415^{* *}$ & $.590^{* *}$ & $.542^{* *}$ & 1 & & \\
\hline ENV 5 & $.487^{* *}$ & $.491^{* *}$ & $.554^{* *}$ & $.427^{* *}$ & 1 & \\
\hline ENV 6 & $.471^{* *}$ & $.480^{* *}$ & $.421^{* *}$ & $.530^{* *}$ & $.303^{* *}$ & 1 \\
\hline
\end{tabular}

**. Correlations is significant at the 0.01 level (2-tailed)

In Table 9, the result of the two-tailed Mann-Whitney $U$ test was insignificant at age $(U=$ $737.50, z=-0.004, p>.01, r=.000)$, gender $(U=784.00, z=-1.224, p>.01, r=.122)$, and education level age $(U=737.50, z=-0.004, p>.01, r=.000)$. Therefore, perceptions of CSR based on respondent's age, gender and education level didn't vary significantly. 


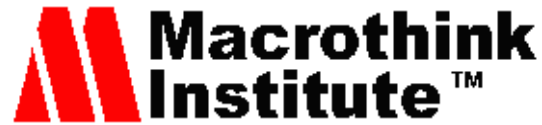

Business and Economic Research ISSN 2162-4860 2022, Vol. 12, No. 1

Table 9. Two-Tailed Mann-Whitney $U$ Test for the Perception of Students on CSR based on Age, Gender and Education Level

\begin{tabular}{|l|l|l|l|l|l|l|l|}
\hline Variables & Respondent's Groups & $\mathrm{N}(\mathrm{n}=100)$ & Mean Rank & $U$ & $\mathrm{Z}$ & $\mathrm{p}$ & $\mathrm{r}$ \\
\hline \multirow{2}{*}{ Perceptions on CSR } & $16-22$ years ages & 82 & 50.49 & 737.50 & -.004 & .996 & .000 \\
\cline { 2 - 7 } & $23-30$ years ages & 18 & 50.53 & & & & \\
\hline \multirow{2}{*}{ Perceptions on CSR } & Male & 75 & 52.55 & 784.00 & -1.224 & .221 & .122 \\
\cline { 2 - 5 } & Female & 25 & 44.36 & & & & \\
\hline \multirow{2}{*}{ Perceptions on CSR } & Honours & 82 & 50.49 & 737.50 & -.004 & .996 & .000 \\
\cline { 2 - 4 } & Masters & 18 & 50.53 & & & & \\
\hline
\end{tabular}

Table 10 displays the result of the Kruskal-Wallis $H$ test, and there was a significant difference in CSR's perception among the students of three universities $(p=0.011)$. On the other hand, there were insignificant differences in perception of CSR based on respondent's educational level at knowing CSR ( $p=0.308)$ and quantity of CSR's learning $(p=0.359)$.

Table 10. Kruskal-Wallis $H$ Test for the Perception of Students on CSR based on University, Education Level at Knowing CSR and Quantity of CSR's Study

\begin{tabular}{|c|c|c|c|c|c|c|}
\hline Variables & Groups & $\mathrm{N}(\mathrm{n}=100)$ & Mean Rank & Kruskal-Wallis $H$ & $\mathrm{df}$ & $\mathrm{p}$ \\
\hline \multirow[t]{3}{*}{ Perception } & University of Rajshahi & 67 & 45.27 & \multirow[t]{3}{*}{9.028} & \multirow[t]{3}{*}{2} & \multirow[t]{3}{*}{.011} \\
\hline & University of Dhaka & 14 & 70.21 & & & \\
\hline & Begum Rokeya University, Rangpur & 19 & 54.42 & & & \\
\hline \multirow[t]{3}{*}{ Perception } & Secondary School Certificate (SSC) & 28 & 43.70 & \multirow[t]{3}{*}{2.356} & \multirow[t]{3}{*}{2} & \multirow[t]{3}{*}{.308} \\
\hline & Higher Secondary Certificate (HSC) & 51 & 52.15 & & & \\
\hline & Honours (Undergraduate) & 21 & 55.57 & & & \\
\hline \multirow[t]{3}{*}{ Perception } & A chapter & 55 & 54.21 & \multirow[t]{3}{*}{2.049} & \multirow[t]{3}{*}{2} & \multirow[t]{3}{*}{.359} \\
\hline & A topic of chapter & 30 & 46.60 & & & \\
\hline & A subject/course & 15 & 44.70 & & & \\
\hline
\end{tabular}

Table 11 shows the weighted average mean score of the $21^{\text {st }}$ items under three dimensions was 4.20, indicating the positive perception among business faculty students. But student's understanding varied among three SDGs dimensions. Respondents perceived economic and social dimensions similarly having weighted average mean, 4.36 and 4.34, respectively. Elsewhere, their consciousness of environmental issues was comparatively low, resulting WAM score of 3.84 as the result of Moyeen \& West (2014).

Table 11. Weighted Average Mean of Three Dimensions

\begin{tabular}{|l|l|}
\hline Dimensions & Weighted Average Mean (WAM) \\
\hline Economic & 4.36 \\
\hline Social & 4.34 \\
\hline Environmental & 3.84 \\
\hline
\end{tabular}

Table 12 depicts the relationship between CSR comprising four responsibilities of Carroll and three dimensions of SDGs. Twenty-one CSRs items were mentioned previously, related to seventeen SDGs. SDG 1, SDG 8, SDG 9, SDG 10, and SDG 12 were in an economic issue related to three CSR areas except for legal responsibilities. In the same way, SDG 2, SDG 3, SDG 4, SDG 5, SDG 11, SDG 16, and SDG 17 were under the social dimension covered three types of responsibilities. Finally, SDG 6, SDG 7, SDG 13, SDG 14, and SDG 15 were 
environmental issues focused on all but economic-based CSR activities.

Table 12. CSRs and SDGs Matrix

\begin{tabular}{|c|c|c|c|c|}
\hline \multirow{7}{*}{ CSR } & \multicolumn{4}{|l|}{ SDGs } \\
\hline & & $\begin{array}{l}\text { SDG 1, SDG 8, } \\
\text { SDG 9, SDG 10, } \\
\text { SDG } 12\end{array}$ & $\begin{array}{l}\text { SDG } 2, \text { SDG 3, SDG 4, } \\
\text { SDG 5, SDG } 11, \\
\text { SDG } 16, \text { SDG } 17\end{array}$ & $\begin{array}{l}\text { SDG 6, SDG 7, } \\
\text { SDG 13, SDG 14, } \\
\text { SDG 15 }\end{array}$ \\
\hline & & $\begin{array}{l}\text { Economic } \\
\text { dimension }\end{array}$ & $\begin{array}{l}\text { Social } \\
\text { dimension }\end{array}$ & $\begin{array}{l}\text { Environmental } \\
\text { dimension }\end{array}$ \\
\hline & $\begin{array}{l}\text { Philanthropic } \\
\text { responsibilities }\end{array}$ & $\begin{array}{l}\text { ECO 1, ECO 5, } \\
\text { ECO } 6\end{array}$ & $\begin{array}{l}\text { SCO } 2, \operatorname{SCO} 3, \operatorname{SCO} 4, \\
\text { SCO } 5, \operatorname{SCO} 7, \\
\text { SCO } 8, \operatorname{SCO} 9\end{array}$ & ENV 2 \\
\hline & Ethical responsibilities & $\mathrm{ECO} 4$ & $\mathrm{SCO} 1$ & ENV 4, ENV 6 \\
\hline & Legal responsibilities & & & ENV 1, ENV 3, ENV 5 \\
\hline & Economic responsibilities & $\mathrm{ECO} 2, \mathrm{ECO} 3$ & SCO 6 & \\
\hline
\end{tabular}

From the above result and discussion here, hypothesis 1 and 3 were matched with analysis and accepted. On the other hand, hypothesis 2 didn't assimilate thoroughly with the presumption and was rejected.

\section{Conclusion}

CSRs impact humanity, society, the economy, and the environment through numerous manners related to various modes of SDGs. It has direct and indirect impacts on various dimensions of SDGs. So, it is imperative to carry out CSR activities for the implementation of UN agenda 2030 successfully. Respondent's Knowledge of CSR was acceptable. Besides, there was a favourable perception level among business faculty students in Bangladesh, but it varied in different goals of SDGs. Environmental issues were perceived comparatively low than economic and social issues. However, business faculty students have enormous scope to participate in business operations and policy making. It is vital to have a higher perception level on CSRs among them to achieve Sustainable Development Goals.

This research was not from limitations. Initially, only three universities students were selected. Secondly, the sample size was small and the areas of CSR activities were limited. Lastly, only one faculty students were chosen. Further studies can be conducted with a large sample size for strengthening validity and reliability. Future research having more public and private university students, including different areas, can improve acceptability. Similarly, conducting research having huge number of CSR activities are essential for enhancing quality.

The research will inspire policymakers of a country to focus on CSR for the proper execution of SDGs. Besides, it is helpful for business organizations to handle CSR activities carefully for their development and the betterment of the whole community. In this case, comprehensive learning programs on CSR can be the best tools for enhancing the knowledge and the perception among learners. Thus, educational institutions can achieve SDGs by expanding CSR knowledge and perception among students. 


\section{Acknowledgement}

The authors want to thank all participants for their time and contributions. The authors funded this paper.

\section{References}

Adámek, P. (2013). Corporate Social Responsibility Education in the Czech Republic. Procedia - Social and Behavioral Sciences, 106, 730-738.

https://doi.org/10.1016/j.sbspro.2013.12.084

Adda, G., Azigwe, J. B., \& Awuni, A. R. (2016). Business ethics and corporate social responsibility for business success and growth. European Journal of Business and Innovation Research, 4(6), 26-42. https://doi.org/10.37745/ejbir.2013

Akoglu, H. (2018). User's guide to correlation coefficients. Turkish Journal of Emergency Medicine, 18(3), 91-93. https://doi.org/10.1016/j.tjem.2018.08.001

Albareda-Tiana, S., Vidal-Raméntol, S., \& Fernández-Morilla, M. (2018). Implementing the sustainable development goals at the university level. International Journal of Sustainability in Higher Education, 19(3), 473-497. https://doi.org/10.1108/IJSHE-05-2017-0069

Behringer, K., \& Szegedi, K. (2016). The Role of CSR in Achieving Sustainable Development - Theoretical Approach. European Scientific Journal, ESJ, 12(22), 10-25. https://doi.org/10.19044/esj.2016.v12n22p10

Belal, A. R., \& Roberts, R. W. (2010). Stakeholders' Perceptions of Corporate Social Reporting in Bangladesh. Journal of Business Ethics, 97(2), 311-324.

https://doi.org/10.1007/s10551-010-0511-4

Boubakary \& Moskolaï, D. D. (2016). The influence of the implementation of CSR on business strategy: An empirical approach based on Cameroonian enterprises. Arab Economic and Business Journal, 11(2), 162-171. https://doi.org/10.1016/j.aebj.2016.04.001

Carroll, A. B. (1991). The pyramid of corporate social responsibility: Toward the moral management of organizational stakeholders. Business Horizons, 34(4), 39-48.

https://doi.org/10.1016/0007-6813(91)90005-G

Chan, T. J., \& Hasan, N. A. M. (2019). Internal corporate social responsibility practices and employees' job satisfaction in a Malaysian banking company. Jurnal Pengurusan, 55, 97-109. https://doi.org/10.17576/pengurusan-2019-55-08

Chauhan, K., \& Dawra, S. (2017). Aligning Corporate Social Responsibility (CSR) Towards Sustainable Development (SD) -an Indian Perspective. International Journal of Management and Applied Science (IJMAS), 3(8), 39-49.

Clark, L. A., \& Watson, D. (1995). Constructing Validity: Basic Issues in Objective Scale Development. Psychological Assessment, 7(3), 309-319.

https://doi.org/10.1037/1040-3590.7.3.309 
Davis, K. (1973). The Case for and Against Business Assumption of Social Responsibilities. Academy of Management Journal, 16(2), 312-322. https://doi.org/10.5465/255331

De Burgh-Woodman, H., \& Saha, A. (2014). The Role of Business Education in Building Business Leadership for 21st Century Responsiveness and Environmental Stewardship: Should Business Education Be Re-Developed? Proceedings of the International Association for Business and Society, 25, 305-310. https://doi.org/10.5840/iabsproc20142532

ElAlfy, A., Palaschuk, N., El-Bassiouny, D., Wilson, J., \& Weber, O. (2020). Scoping the evolution of corporate social responsibility (CSR) research in the sustainable development goals (SDGs) era. Sustainability (Switzerland), 12(14), 1-21.

https://doi.org/10.3390/su12145544

García-Feijoo, M., Eizaguirre, A., \& Rica-Aspiunza, A. (2020). A systematic review of sustainable-development-goal deployment in business schools. Sustainability (Switzerland), 12(1), 1-19. https://doi.org/10.3390/su12010440

Gupta, R. (2019). Evaluating the contribution of CSR in achieving UN's sustainable development goals. Amity Journal of Corporate Governance, 4(1), 43-59.

https://amity.edu/UserFiles/admaa/93baePaper\%204.pdf

Hieu, P. D. (2011). Corporate social responsibility: A study on awareness of managers and consumers in Vietnam. Journal of Accounting and Taxation, 3(8), 162-170.

https://doi.org/10.5897/JAT11.022

Hunady, J., Orviska, M., \& Pisar, P. (2018). The effect of higher education on entrepreneurial activities and starting up successful businesses. Inzinerine Ekonomika-Engineering Economics, 29(2), 226-235. https://doi.org/10.5755/j01.ee.29.2.19069

Islam, T., Islam, R., Pitafi, A. H., Xiaobei, L., Rehmani, M., Irfan, M., \& Mubarak, M. S. (2021). The impact of corporate social responsibility on customer loyalty: The mediating role of corporate reputation, customer satisfaction, and trust. Sustainable Production and Consumption, 25, 123-135. https://doi.org/10.1016/j.spc.2020.07.019

Ismail, R. (2011). Development and awareness of Corporate Social Responsibility in the perspective of Bangladesh. Asian Transactions on Basic \& Applied Sciences, 01(03), 11-28.

Jimenez, D., Franco, I. B., \& Smith, T. (2021). A Review of Corporate Purpose: An Approach to Actioning the Sustainable Development Goals (SDGs). Sustainability, 13(7), 1-21.

https://doi.org/10.3390/su13073899

Juneja, S. (2014). CSR and Sustainable Development. International Research Journal of Management Science \& Technology, 5(2), 252-264. https://doi.org/10.32804/IRJMST

Karabasevic, D., Petrovic, G., \& Maksimovic, M. (2016). The impact of the levels of education on the perception of corporate social responsibility. Poslovna Ekonomija - Business Economics, 10(2), 106-117. https://doi.org/10.5937/poseko10-12322

Karras, D. J. (1997). Statistical methodology: II. Reliability and validity assessment in study 
design, part B. Academic Emergency Medicine, 4(2), 144-147.

https://doi.org/10.1111/j.1553-2712.1997.tb03723.x

Khatun, M. M. (2014). Corporate Social Responsibility in Bangladesh: The Law and Practices. Journal of Law, Policy and Globalization, 31, 10-18. https://doi.org/10.7176/JLPG

Kish, L. (1965). Survey Sampling. John Wiley and Sons, Inc.

https://doi.org/10.1002/bimj.19680100122

Kot, S. (2014). Knowledge and understanding of corporate social responsibility. Journal of Advanced Research in Law and Economics, 5(2), 109-119.

Lu, J., Ren, L., Yao, S., Qiao, J., Mikalauskiene, A., \& Streimikis, J. (2020). Exploring the relationship between corporate social responsibility and firm competitiveness. Economic Research-Ekonomska Istrazivanja, 33(1), 1621-1646.

https://doi.org/10.1080/1331677X.2020.1761419

Mahmud, A., Ding, D., \& Hasan, M. M. (2021). Corporate Social Responsibility: Business Responses to Coronavirus (COVID-19) Pandemic. SAGE Open, 11(1), 1-17.

https://doi.org/10.1177/2158244020988710

Mahmud, A., Ding, D., Kiani, A., \& Hasan, M. M. (2020). Corporate Social Responsibility Programs and Community Perceptions of Societal Progress in Bangladesh: A Multimethod Approach. SAGE Open, 10(2), 1-17. https://doi.org/10.1177/2158244020924046

Mai, N. P. (2013). Implementing Corporate Social Responsibility towards Sustainable Development: A Case Study of SMEs in Thanh Hoa Province. VNU Journal of Economics and Business, 29(5E), 67-80.

Masum, M. H., Uddin, M. M., Ahmed, H., \& Uddin, M. H. (2019). Corporate social responsibility disclosures and corporate performance: Evidence from the listed companies in Bangladesh. Academy of Strategic Management Journal, 18(2), 1-16.

Moyeen, A., \& West, B. (2014). Promoting CSR to foster sustainable development: Attitudes and perceptions of managers in a developing country. Asia-Pacific Journal of Business Administration, 6(2), 97-115. https://doi.org/10.1108/APJBA-05-2013-0036

Nazri, M. A., Omar, N. A., \& Mohd Hashim, A. J. (2018). Corporate social responsibility and market orientation: An integrated approach towards organizational performance. Jurnal Pengurusan, 52, 121-132. https://doi.org/10.17576/pengurusan-2018-52-10

Ndiweni, E., Haque, F., \& Hassan, M. K. (2018). Corporate social responsibility practices of banks in Bangladesh: A structuration theory perspective. Investment Management and Financial Innovations, 15(1), 350-360. http://dx.doi.org/10.21511/imfi.15(1).2018.29

Nguyen, H. T., Le, D. M. D., Ho, T. T. M., \& Nguyen, P. M. (2020). Enhancing sustainability in the contemporary model of CSR: a case of the fast fashion industry in developing countries. Social Responsibility Journal, 17(4), 578-591. https://doi.org/10.1108/SRJ-03-2019-0108

Nguyen, T. T. B., \& Huang, Q.-W. (2020). Impact of gender and education on corporate 
social responsibility: evidence from Taiwan. Problems and Perspectives in Management, 18(1), 334-344. http://dx.doi.org/10.21511/ppm.18(1).2020.29

Pattanaro, G., \& Donato, S. (2018). Sustainable development goals: a business opportunity for tourism companies? Ekonomiczne Problemy Turystyki, 43, 21-27.

https://doi.org/10.18276/ept.2018.3.43-02

Pedersen, C. S. (2018). The UN Sustainable Development Goals (SDGs) are a Great Gift to Business! Procedia CIRP, 69, 21-24. https://doi.org/10.1016/j.procir.2018.01.003

Rahim, M. M., \& Wisuttisak, P. (2013). Corporate Social Responsibility-Oriented Compliances and SMEs Access to Global Market: Evidence from Bangladesh. Journal of Asia-Pacific Business, 14(1), 58-83. https://doi.org/10.1080/10599231.2013.741417

Rana, M. (2015). Corporate Social Responsibility (CSR): Opportunities and Challenges of Banking Sector in Bangladesh. Journal of Finance and Accounting, 3(6), 234-246.

https://doi.org/10.11648/j.jfa.20150306.20

Rendtorff, J. D. (2019). Sustainable Development Goals and progressive business models for economic transformation. Local Economy, 34(6), 510-524.

https://doi.org/10.1177/0269094219882270

Singh, K., \& Misra, M. (2021). The evolving path of CSR: toward business and society relationships. Journal of Economic and Administrative Sciences.

https://doi.org/10.1108/JEAS-04-2020-0052

UNIDO. (2002). Corporate Social Responsibility - Implications for Small and Medium Enterprises in Developing Countries. [Online] Available: https://www.unido.org/

Tools4dev. (2021). How to choose a sample size. [Online] Available:

https://tools4dev.org/resources/how-to-choose-a-sample-size/

Van der Waal, J. W. H., Thijssens, T., \& Maas, K. (2021). The innovative contribution of multinational enterprises to the Sustainable Development Goals. Journal of Cleaner Production, 285. https://doi.org/10.1016/j.jclepro.2020.125319

Vázquez, J. L., Lanero, A., \& Licandro, O. (2013). Corporate social responsibility and higher education: Uruguay university students' perceptions. Economics and Sociology, 6(2), 145-157. https://doi.org/10.14254/2071-789X.2013/6-2/13

\section{Copyright Disclaimer}

Copyright for this article is retained by the author(s), with first publication rights granted to the journal.

This is an open-access article distributed under the terms and conditions of the Creative Commons Attribution license (http://creativecommons.org/licenses/by/4.0/). 